\title{
Effect of Different Carbohydrates on the Rumen Fermentation and Nitrogen Utilization in Silage-fed Ruminants
}

\author{
Hiroshi Fujita \\ Laboratory of Animal Nutrition, Obihiro University of \\ Agriculture and Veterinary Medicine, Obihiro-shi 080
}

(Received June 27, 1977)

\begin{abstract}
A comparative study was made to determine the effect of easily fermentable carbohydrates on the efficiency of utilization of silage nitrogen as well as the patterns of rumen fermentation in the silage-fed ruminants. To facilitate this, four Corriedale wethers (including two which were rumen fistulated) were used for the nitrogen balance trial and for the determination of general properties of the rumen fluid in a $4 \times 4$ Latin square experimental design with four dietary treatments as follows; (1) grass silage alone, as a control diet, (2) silage with starch, (3) silage with sucrose and (4) silage with glucose. The addition of the above three types of carbohydrates significantly improved the nitrogen retention of the wethers receiving silage as a sole diet, but there were no appreciable differences between the three experimental diets supplemented with different carbohydrates. Ammonia concentration in the rumen differed markedly between diets, being highest on the control diet and lowest on the glucose diet throughout the sampling period after feeding. Also, there was a rapid fall in ruminal $\mathrm{pH}$ during the initial period after feeding on all the carbohydrate-supplemented diets as compared with the control diet. The fall in ruminal $\mathrm{pH}$ and the increase in the total concentration of VFA during the initial period were prominent in the starch diet. The relative proportions of VFA differed clearly among the diets examined.
\end{abstract}

Concerning the changes in the composition of the nitrogenous fraction of grass silage, it has been well established that there is a considerable decline in the protein nitrogen, accompanied by a consistent increase in water-soluble non-protein nitrogen during ensilage. In our previous reports $^{1-3)}$ it was shown that the silage containing a large proportion of the water-soluble nitrogen induced markedly lower nitrogen retention than did hay or good-quality silage containing less non-protein nitrogen (NPN). In addition, the water-soluble fraction of grass silage induced lower nitrogen retention than the residual part of the silage when those were included as major nitrogen sources in rations. On the basis of these results it seemed reasonable to assume that the increase in NPN during ensilage might be a restricting factor of utilization of silage nitrogen by ruminants. In order to make an efficient utilization of silage nitrogen, therefore, it was thought. advisable to investigate further the NPN metabolism in the silage-fed ruminants in relation to the factors promoting protein synthesis from NPN in the rumen.

The present investigation was designed to determine the effect of certain carbohydrates, as easily available energy sources for the efficient use of NPN in the rumen, on the rumen fermentation and in the utilization of silage nitrogen.

Jap. J. Zootech. Sci., 49, (1): 40-46.

1978. 1. 


\section{Materials and Methods}

Silage: The silage was prepared from a first cut mixture of orchardgrass (90\%) and Ladino clover (10\%) harvested with a direct cut forage harvester when the head of orchardgrass was in the early-heading stage of maturity. The forages were ensiled in two, steel, upright silos, $2.4 \mathrm{~m}$ high with a diameter of $1.2 \mathrm{~m}$. After three months of storage, the whole content of the silos was completely removed at one time and preserved by sealing into a number of polyethylene bags at $-20^{\circ} \mathrm{C}$ in freezing chamber untill the metabolism experiment was carried out.

Animal and treatments: Four Corriedale wethers (including two which were rumen-fistulated) of about 4 years of age, weighing $62-68 \mathrm{~kg}$ were used for the nitrogen balance trial and for the determination of general properties of the rumen fluid. A $4 \times 4$ Latin square experimental design was used with the above four wethers and four dietary treatments as follows; (1) silage alone (control), (2) silage with starch, (3) silage with sucrose and (4) silage with glucose.

The wethers were kept in individual metabolism crates, and were offered daily $4.8 \mathrm{~kg}$ silage alone for a control period and $4.8 \mathrm{~kg}$ silage plus $90 \mathrm{gm}$ carbohydrates for other experimental periods. The daily diets were offered in two equal parts at 8:30 AM and 4:30 PM. The length of each experimental period was 14 days, of which the first 7 day served as a preliminary period and the next 5 as a faeces and urine-collection period and the last 2 as a sampling period of rumen fluid. Water and commercial salt licks (KoEN: Nihon Zenyaku Kogyo Co.) were accessible at all times.

Collection of samples: Samples of feed were collected for each period. The faeces and urine were collected once daily and, of the total quantity, $10 \%$ for the faeces and $2 \%$ for the urine were retained for the determination of nitrogen contents. Samples of rumen fluid, consisting of approximately $150 \mathrm{ml}$, were collected at $0,1,2,3,4,6$ and 8 hours after feeding through the rumen fistula for the determination of $\mathrm{pH}$, ammonia nitrogen and volatile fatty acid concentration.

Analytical methods: The chemical composition of the dried samples of feed and faeces were determined by the conventional method adopted by the National Institute of Animal Indust$\mathrm{ry}^{4}$. Nitrogen content of urine was determined by KIELDaHL method. The $\mathrm{pH}$ of the rumen fluid was measured immediately after sampling using conventional glass electrode $\mathrm{pH}$ meter. Concentration of ruminal ammonia was determined by ConwAY's micro-diffusion method ${ }^{5)}$. Total VFA concentration and the proportions of individual VFA (acetic, propionic, n-butyric, iso-butyric, n-valeric and iso-valeric acid) in rumen fluid and silage were determined by gas chromatography, using the technique described by KagEYAMA et al. ${ }^{6)}$ Lactic acid in silage was determined by the method of Barker and Summerson modified by BarnetT ${ }^{7)}$.

The results of the nitrogen balance trial were subjected to analysis of variance. Significance among the differerent treatments was tested by TUKEY's method as modified by SNEDECOR ${ }^{8)}$.

\section{Results and Discussion}

The average chemical quality and chemical composition of silage are shown in Table 1. On the basis of these criteria presented in Table 1, the silage used in the present study proved to be of satisfactory quality.

Mean values for the nitrogen balance trial are presented in Table 2. The excretion of urinary $N$ decreased significantly $(P<0.05)$ on the experimental diets, in which several carbohydrates were given, as compared with the control diet. In consequence, the nitrogen retention was sig- 
Fujita:

Table 1. Chemical quality and chemical composition of the silage

\begin{tabular}{|c|c|c|}
\hline & $\begin{array}{l}\text { Values on fresh } \\
\text { matter basis }\end{array}$ & $\begin{array}{c}\text { Values on dry } \\
\text { matter basis }\end{array}$ \\
\hline Chemical quality & & \\
\hline $\mathrm{pH}$ & 4.21 & - \\
\hline \multicolumn{3}{|l|}{ Organic acids (\%) } \\
\hline Lactic acid & $1.65(69.3) *$ & 8.9 \\
\hline Acetic acid & $0.42(17.6)$ & 2.3 \\
\hline Propionic acid & $0.12(5.0)$ & 0.6 \\
\hline Butyric acid & $0.19(8.0)$ & 1.0 \\
\hline $\mathrm{NH}_{8}-\mathrm{N} /$ Total $\mathrm{N}(\%)$ & 9.7 & - \\
\hline \multicolumn{3}{|c|}{ Chemical composition (\%) } \\
\hline Dry matter & 18. 47 & 100 \\
\hline Crude protein & 2.03 & 11.0 \\
\hline Crude fat & 0.93 & 5.0 \\
\hline NFE & 6.35 & 34.4 \\
\hline Crude fibre & 7.09 & 38.4 \\
\hline Crude ash & 2.07 & 11.2 \\
\hline
\end{tabular}

* Figures in parentheses represent the percentage of total organic acid in silage.

Table 2. Nitrogen balance*

\begin{tabular}{lcccc}
\hline & Control diet & +Starch & +Sucrose & +Glucose \\
\hline N intake (g/day) & 13.8 & 13.8 & 14.0 & 13.3 \\
Faecal N (g/day) & 5.1 & 5.3 & 5.8 & 5.3 \\
Urinary N (g/day) & $8.8^{\mathrm{a} * *}$ & $7.1^{\mathrm{b}}$ & $7.1^{\mathrm{b}}$ & $6.7^{\mathrm{b}}$ \\
Digested N (g/day) & 8.7 & 8.5 & $8.2^{\mathrm{b}}$ & 8.0 \\
Retained N (g/day) & $-0.1^{\mathrm{a}}$ & $1.4^{\mathrm{b}}$ & $1.1^{\mathrm{b}}$ & $1.3^{\mathrm{b}}$ \\
$\mathrm{N}$ digestibility (\%) & 63.1 & 61.5 & 58.5 & 60.1
\end{tabular}

* Values are average for four wethers. are significantly different $(P<0.05)$.

nificantly $(P<0.05)$ greater on the experimental diets than that on the control diet. There were, however, no appreciable differences in urinary nitrogen and retention values of nitrogen between the three experimental diets supplemented with different carbohydrates. As seen in Table 2, the control diet tended to give higher value for nitrogen digestibility than either of the others but the differences between treatments were not significant.

Ruminal ammonia concentrations at the various time-intervals after feeding for two wethers receiving four different diets are illustrated in Figure 1. On all treatments, ruminal ammonia concentration showed a sharp increase during the first hour after feeding and then tended to decrease with increasing time after feeding. In general, the addition of carbohydrates resulted in considerable reductions in the concentration of ruminal ammonia throughout the extended sampling period as compared with control diet. On the experimental diets supplemented with carbohydrates, values declined very rapidly after reaching a maximum level during first hour than was 


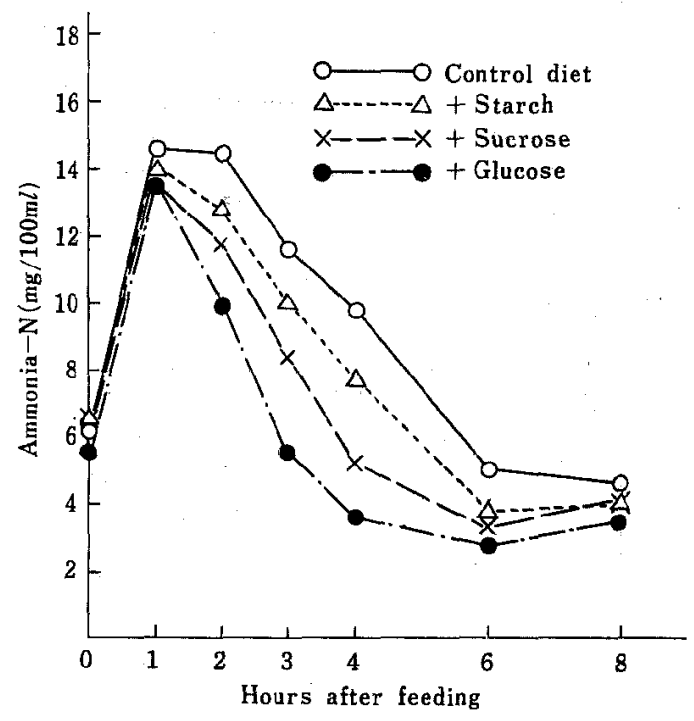

Fig. 1. Changes in concentration of ammonia nitrogen in the rumen fluid. Values are average for two wethers for two consecutive days.

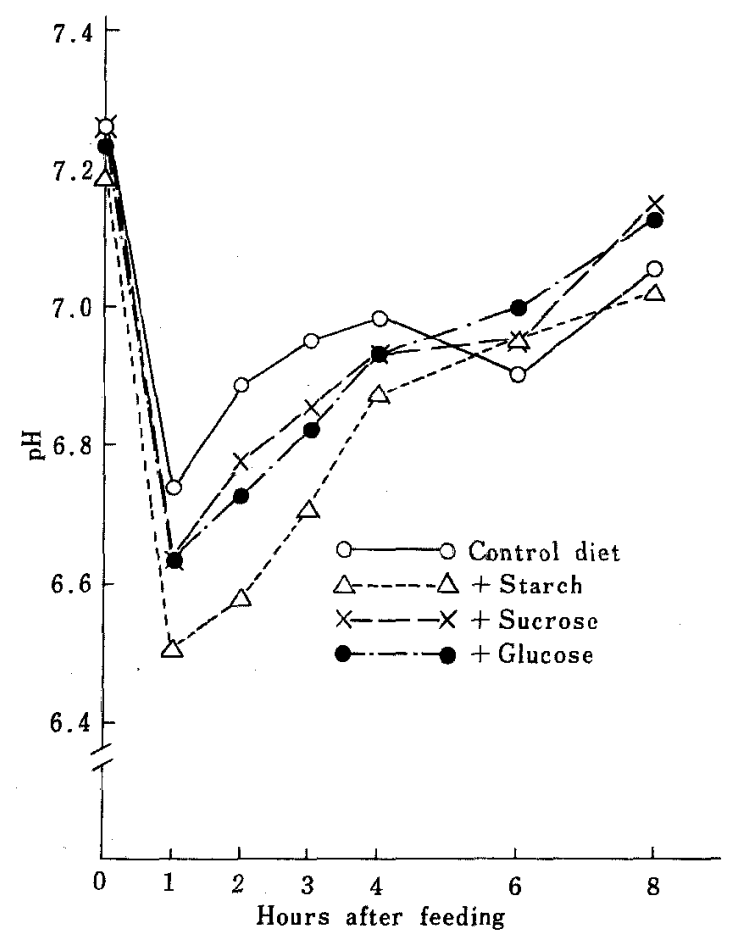

Fig, 2. Changes in $\mathrm{pH}$ of the rumen fluid. Values are average for two wethers for two consecutive days. 


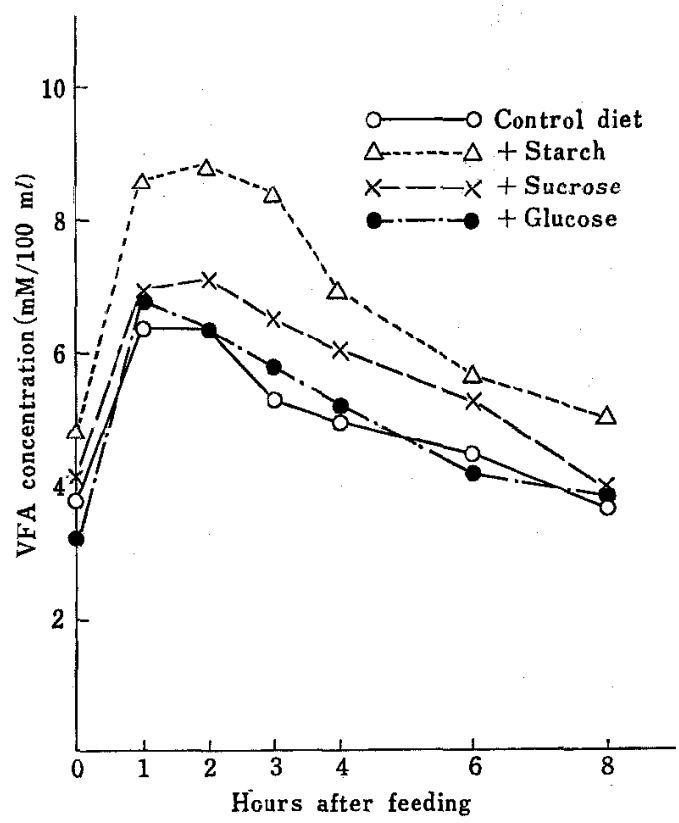

Fig. 3. Changes in total VFA concentration in the rumen fluid. Values are average for two wethers for two consecutive days.

the case in control diet. From the data presented in Figure 1 and Table 2, it was likely that the reduction in concentration of ruminal ammonia is directly related to a higher nitrogen balance, as has been discussed by Chalmers et al. ${ }^{9)}$ However, it should be pointed out that the starch diet showed the highest value for nitrogen retention notwithstanding the higher concentration of minal ammonia as compared with glucose and sucrose diet. Although a definite reason for this rucan not be established it seems probable that the level of ruminal ammonia may not be the only factor capable of regulating the nitrogen balance in the wethers receiving silage diet supplemented with various carbohydrates.

There is some evidence concerning the effect of several carbohydrates on the nitrogen utilization in silage-fed ruminants ${ }^{10,11}$. SYRJ̈̈L̈̈̈${ }^{10}$ showed that the addition of sucrose to grass silage diet caused a higher nitrogen balance and lower ruminal ammonia concentration than the control and starch supplemented diet. Some disagreement was apparent in the present experiment in that starch caused a significant improvement in nitrogen balance. With this respect, FerRando and CATSAOUNIS $^{11)}$ reported that when potato flakes were added to silage ration as a readily available energy source there was a marked reduction in daily excretion of nitrogen in urine and an increased nitrogen retention.

The mean $\mathrm{pH}$ values and the concentrations of total VFA in rumen fluid are shown in Figures 2 and 3. It is apparent that the dietary addition of carbohydrates caused decreases in $\mathrm{pH}$ and increases in the concentration of VFA during 1-4 hours after feeding. Among the experimental diets, the starch supplemented diet showed the lowest $\mathrm{pH}$ values and the highest VFA concentration throughout this period. The patterns of changes in $\mathrm{pH}$, however, did not always correspond with the increasing rate of the total concentration of VFA. 

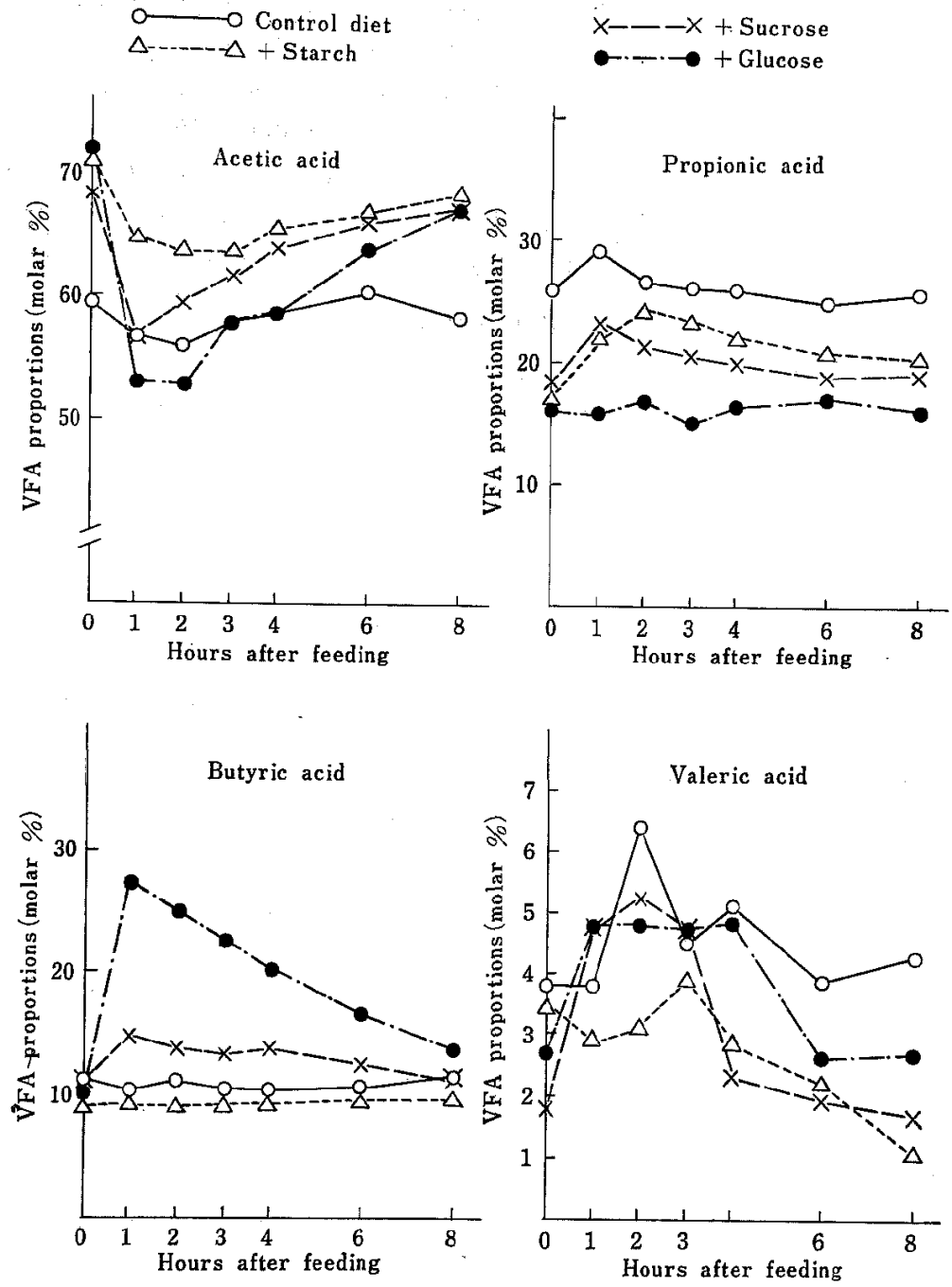

Fig. 4. Changes in molar proportion of VFAs in the rumen fluid. Values are average for two wethers for two consecutive days.

Figure 4 illustrates the effect of the different carbohydrates on the molar proportions of the VFA in the rumen fluid. In the present data, iso-butyric and $n$-valeric acid are not shown because concentrations and changes in the proportions of these acids were very low and negligible. There was a marked increase in the relative concentration of acetic acid during 1 to 6 hours after feeding when starch or sucrose was added. Also, there was a sharp rise in relative concentration of butyric acid and a corresponding drop in propionic and acetic acid when glucose was added. It would be interesting to examine whether this pattern in the relative proportion of VFA is characteristic of the ration containing grass silage as a main component; the relationship be tween the patterns of VFA and the utilization of silage nitrogen remains to be investigated.

Considering the role of easily fermentable carbohydrates in NPN utilization in the rumen, it could be assumed that an adequate supply of several carbohydrates promote more efficient micro- 
bial protein synthesis from silage nitrogen since the grass silage contained a large proportion of NPN, particularly in the form of ammonia and free amino acids ${ }^{1-3,12-14)}$, which may result in more ammonia absorption from the rumen. In the present experiment carbohydrates were given at ca. $10 \%$ of dry matter of the silage. This amount of carbohydrates added was equivalent to 6. 4 times of the total nitrogen intake from silage diet ingested. There is a lack of information on the quantitative aspects of the adequate ratio of easily fermentable carbohydrate to total nitrogen for the efficient utilization of silage nitrogen; further studies on this point are clearly needed.

\title{
References
}

1) FujitA, H., and M. JinBu, Jap. J. Zootech. Sci., 44: 615 622. 1973.

2) Fujita, H., and K. Katsumata, Jap. J. Zootech. Sci., 46: 347-352. 1975.

3) Fujita, H., Jap. J. Zootech. Sci., 47: 224-232. 1976.

4) National Institute of Animal Industry, Special report of the National Institute of Animal Industry, No. 3, 7-8. 1964.

5) Conway, E. J., Microdiffusion Analysis and Volumetric Error, 3rd ed. (Translated into Japanese by O. IshisaKa) 82-84. Nankodo. Tokyo. 1957.

6) Kageyama, K., H. Mori., and K. Sato, Jap. J. Zootech. Sci., 44: 465-469. 1973.

7) Barnetr, A. J.G., Silage Fermentation, 146-147. Butterworths Scientific Publications. London. 1954.

8) Snedecor, G. W., Statistical Methods, 5th ed. 251-253. The Iowa State University Press. Ames. Iowa. 1956.

9) Chalmers, M. I., D. P. Cuthbertson and R. L. M. Synge, J. Agric. Sci., 44: 254-262. 1954.

10) SyrjäLё, L., Annales Agriculturae Fenniae, 11: 201-276. 1972. (Cited from Ntur. Abstr. Rev., 43: 749. 1973.)

11) Ferrando, R., and N. Catsaounis, Ann. Nutrition Aliment, 20: 127-145. 1966.

12) ОhуамA, Y., and S. Masaki, Jap. J. Zootech. Sci., 40: 249-254. 1969.

13) Ohyama, Y., Jap. J. Zootech. Sci., 40: 334-340. 1969.

14) Hughes, A. D., J. Agr. Sci. Camb., 75: 421-431. 1970.

\section{牧草サイレージ給与時における反劉家畜の第一胃内発酵 および窒素利用性におよぼす炭水化物投与の影響}

\author{
藤田裕 \\ 州広畜産大学，帯広市 080
}

反倠家畜に扔ける牧草サイレージ中窒素化合物の利用 性に関与する要因莸明らかにするため, 易発酵性岸水化 物の投与がメン羊の第一胃内発醉および窒素蓄積におよ ぼす影留を検討した，供試炭水化物としては，デンプ ン、ショ糖於よびグルコースを用い，それぞれ牧草サイ レージ単独給与赫を対照として, 各炭水化物をサイレー ジに添加給与した場合の窒素出納量および第一胃内性状 の变化計測した：これらの炭水化物投与により，空䕀 蓄榴量はサイレージ単給時にくらべていずれる有意に増 加したが，投与炭水化物の種類による差は認められなか
った、第一胃内アンモニア浱度は炭水化物投与により明 らかに低下し，とくにグルコース投与時に低下の割合が 高加た。炭水化物投与の場合は，いずれも給飼当初の $\mathrm{pH}$ 低下が対照飼料にくらべて著しく，とくにデンブン 投与㭙にその傾向が強かった，第一胃内 VFA 組成は， 投与炭水化物の種類により変動し，デンプン投与時には 酢酸の割合が，ダルコース投与時には酪酸の割合が対照 始料にくらべて高く，ブロビオン酸の割合は，いずれの 炭水化物投与の場合む対照飼料にくらべて低く推移し た。 